\title{
Diz çevresi osteotomilerinde kıkırdak rejenerasyonunu artırıcı uygulamalar
}

\section{Applications to increase cartilage regeneration in osteotomies around the knee}

\author{
Mehmet Emin Şimşek¹, Murat Bozkurt² \\ ${ }^{1}$ Lokman Hekim Üniversitesi, Ortopedi ve Travmatoloji Anabilim Dalı, Ankara \\ ${ }^{2}$ Yıldırım Beyazıt Üniversitesi, Ortopedi ve Travmatoloji Anabilim Dalı, Ankara
}

\begin{abstract}
Eklem koruyucu cerrahiler, uzun süreli yaşam beklentisi ve günlük aktivitelerden artan beklentilerin bir sonucu olarak eklem kıkırdağı hasarının tedavisinde önem kazanmıştır. Osteoliz, mekanik gevşeme, eklem enfeksiyonu, bağ gevşekliği veya kemik kaybına bağlı problemli revizyon cerrahileri gereksinimleri gibi artroplastinin olası kötü sonuçları nedeniyle, eklem koruyucu cerrahi tedavilerden olan diz çevresi osteotomileri ve kıkırdak onarım cerrahilerinin daha fazla tercih edilmesine yol açmıştır. Diz çevresi osteotomi cerrahisinin amacı, deformite bölgesinde dizilimi düzeltmek ve hasarlı kıkırdak üzerindeki baskıyı hafifletmektir. Genç hastalara yardımcı olmak için tasarlanmış tedavi algoritmalarında osteotomi kullanılacaksa, geçmişte osteotomilerden hoşnutsuzluğa yol açan teknikle ilgili sorunlardan ve hasta ile ilgili sorunlardan kaçınılmalıdır. Genç hastalarda eklem koruyucu cerrahi gelişmekte olan bir alan olduğundan, genellikle cerrahlar için kafa karıştırıcıdır. Bu bölümün amacı, diz çevresi osteotomilerinden sonra kıkırdak rejenerasyonunu artırıcı uygulamalara pratik bir yaklaşım sağlamaktır. Diz çevresi osteotomileri sonrası kıkırdak rejenerasyonunu artırıcı bazı cerrahi teknikler açıklanmıştır.
\end{abstract}

Anahtar sözcükler: eklem kıkırdağı; diz osteotomisi; kıkırdak onarımı; kıkırdak rejenerasyonu
Joint preservation surgery has achieved an importance in the treatment of articular cartilage damage as a result of prolonged life expectancy and increased expectations from daily activities. With the inherent problems of prosthetic arthroplasty failure due to polyethylene osteolysis, mechanical loosening, joint infection, and problematic revision surgery secondary to ligamentous laxity or bone deficiency, reevaluation of joint preservation techniques led to the resurgence of osteotomy and cartilage repair surgeries as well as more bone-sparing partial prosthetic arthroplasties. The purpose of the knee osteotomy surgery is to correct malalignment at the site of the deformity and relieve pressure on the damaged cartilage. If osteotomy is to be used in treatment algorithms designed to help these young patients, then the technique-related problems and patient-related issues that led to disfavor with tibial osteotomy in the past must be avoided. Because joint preservation in young patients is a developing field, it is often confusing to surgeons. The purpose of this chapter is to provide a practical approach to the field of cartilage regenaration after knee osteotomies. Some surgical techniques have been explained combining previous principles of knee osteotomies and cartilage regeneration techniques.

Key words: articular cartilage; knee osteotomy; cartilage repair; cartilage regeneration
$\mathbf{N}$ ormal diz eklemi, dejeneratif değişiklikler gelişmeden ömür boyu tekrarlanan yüklenmeyi karşılayabilmektedir. Eklem kıkırdağının toleransını aşan aşırı stres, eklem kıkırdağının bozulmasına yol açarak eklem homeostazisini bozar. Fizyolojik durumda, diz eklemine uygulanan yük bölmeler arasında dağıtılır. Diz eklemi doğal hizalamasında bir sapma, yük dağılımını olumsuz etkiler. Yanlış yük dağılımı, diz ekleminin eklem kıkırdağına zarar verebilecek fizyolojik kuvvetlere dayanma yeteneğini azaltır. ${ }^{[1]}$
Eklem kıkırdağı lezyonlarının kendiliğinden onarım potansiyeli yoktur ve zamanla oluşan lezyonların kötüleşme eğilimi vardır. Tibio-femoral ve patello-femoral hizalamanın bozulmuş olması, eklem laksitesi, kontraktürleri, menisküs yırtıkları, biyolojik ve genetik yatkınlık kıkırdak hasarlarının oluşumuna ve ilerlemesine neden olabilmektedir.

Kıkırdak lezyonları tedavisi en zor patolojilerden biridir. Konservatif tedaviler semptomları hafifletemediğinde ve fonksiyonel sınırlamalar düzelmediğinde,

- Illetişim adresi: Murat Bozkurt, MD, PhD, Ankara Yıldırım Beyazıt Üniversitesi, Ortopedi ve Travmatoloji Anabilim Dalı, 06800 Ankara, Türkiye Tel: 0532 - 2831639 e-posta: nmbozkurt@gmail.com

- Geliș tarihi: 2 Mart $2020 \quad$ Kabul tarihi: 21 Mart 2020 
genellikle hem kıkırdak defekti hem de altta yatan anatomik anormallikleri tedavi etmek için iyi bir cerrahi planlama gerekmektedir. ${ }^{[2]}$

Bu lezyonlar teknik olarak kolay erişilebilir olmasına rağmen, eşlik eden patolojilerin analizi zordur. Bu nedenle spesifik bir tedavi planlamak için diz ekleminin hizalamasında patolojik sapmayı sistematik olarak değerlendirmek ve tanımlamak için her patolojik bileşeni ayrı ayrı ele alarak rasyonel bir yaklaşım gereklidir. Kıkırdak tedavilerinin başarısı iyi hizalanmış eklemden geçmektedir ve bu tedaviler sonrası kıkırdak rejenerasyonunu sağlamak için kullanılabilecek tedavi seçeneklerinin her birini ayrı ayrı göz önünde tutulması gerekmektedir.

\section{KIKIRDAK REJENERASYONUNU ARTIRMAK IÇIN OSTEOTOMI GEREKLI MIDIR?}

\section{Tibio-Femoral Hizalamanın Kıkırdak Lezyonlarına Etkisi}

Normal bir yürüyüş sırasında, diz reaksiyon kuvvetleri vücut ağırlı̆ının üç katına ulaşır ve daha yüksek aktivite seviyeleri sırasında vücut ağırlığının altı katına kadar çıkabilemektedir. Normal olarak hizalanmış bir dizde, ağırlık taşıma kuvvetinin yaklaşık \%60'ı medial kompartmandan iletilir. Biyomekanik çalışmalar varus ve valgus hizalamasının sırasıyla medial ve lateral yükü artırdığını göstermiştir. Buna göre uyumsuzluk, diz osteoartritinin $(\mathrm{OA})$ gelişimi ve ilerlemesi için bağımsız bir risk faktörü olarak kabul edilmiştir. ${ }^{[3]}$ On sekiz aylık takipten sonra, valgus ile hizalanmış bir diz, nötral hizalı dizlere kıyasla lateral kompartman OA'nın ilerleme olasılığını beş kat artırır; benzer şekilde, varus hizalı bir dizde medial OA'nın ilerleme riskini dört kat artırır. Tibio-femoral eklem kuvvetlerini normalleştirmek için düzeltici osteotomi, hastalığın ilerlemesini durduracak ve kıkırdak onarımı durumunda, eklem yüzeyinin en uygun şekilde yeniden oluşturulması için ortamı iyileştirecektir. ${ }^{[4]}$

\section{Patello-Femoral Hizalamanın Kıkırdak Lezyonlarına Etkisi}

Klinik olarak Q açısının ölçümü ile ekstansör mekanizmanın hizalanması değerlendirilebilir. Kuadriseps kuvvet yönü olarak tanımlanır ve bu açı ekstansör mekanizma kuvvetinin lateral vektörünü belirler. Yaygın olarak tartışılan yanlışlık potansiyeline rağmen $\mathrm{Q}$ açısının klinik ölçümü, kuadriseps kasının patellofemoral (PF) hizalanma üzerindeki etkisini anlamada çok önemlidir. Patellofemoral uyumsuzluk, geniş bir klinik görünüm yelpazesine sahip karmaşık bir patolojidir. ${ }^{[5]}$ Çeşitli özellikler $\mathrm{Q}$ açısını ve sonuç olarak PF reaksiyon kuvvetlerini etkileyebilir. PF uyumsuzluğun en sık anatomik anormalliklerin birleşmesinin bir sonucu olması nedeniyle tek tanımlayıcı etiyolojik faktör olamaz. Bu nedenle, her durumda en uygun yaklaşımı uygulayabilmek için genel bir patoloji anlayışı çok önemlidir.

Patellar lateral uyumsuzluk, patella baja ve infrapatellar yağ dokusunun artrofibrozu, patellofemoral eklemin eklemlenmesi sırasında anormal kuvvetlere neden olur. İzole lateral patellar fasette artritik değişiklikleri lateral PF uyumsuzluk sonucu ile gelişebilir. Patellar eklem kaybı patella baja ve patellar eklem kontraktüründe daha yaygın görülmektedir (Şekil 1). ${ }^{[6]}$

\section{OSTEOTOMI SONRASI KIKIRDAK REJENERASYONUNU ARTIRICI UYGULAMALAR}

Eklem kıkırdağı sinir kaynağından yoksundur. Kıkırdak, zengin şekilde innerve edilen subkondral kemik plağını uyarır. Eklem kıkırdağı hasar gördügünde, subkondral kemik plağının temasından dolayı ağrı oluşabilir. İyileşme yanıtı gelişmezse, hasara maruz kalan subkondral kemiğe iletilen yükler, kondral defektlerin omuzları tarafından yüklenecektir. Bu durum, kusurun kademeli olarak genişlemesiyle birlikte hasarlı kıkırdağın kenarlarının aşırı yüklenmesine ve bozulmasına neden olacaktır. Karşı eklem kıkırdak yüzeyinin etkisi ile oluşan aşınma sonucu çıplak bir kemik yüzeyi ortaya çıkacaktır. ${ }^{[2]}$ Kıkırdak onarımı kısa vadede semptomları hafifletmek ve uzun vadede eklemin kademeli olarak bozulmasını ve osteoartrit gelişimini önlemek için yararlı olacaktır. Bu nedenle, kıkırdak onarımının amacı defekti dolduracak, eklem kıkırdağı ve subkondral kemik plağı ile entegre olacak, aynı viskoelastik mekanik özelliklere sahip olacak ve yapısını bozulmadan zaman içinde koruyacak bir doku üretilmesini sağlamaktır. Yani, osteokondral fonksiyonel üniteyi rejenerasyona yaklaşan bir onarım dokusu ile restore etmektir. Klinik ve deneysel kanıtlar, eklem kıkırdak yüzeyini içeren ve kıkırdakla sınırlı hasarın çok az restorasyona uğradığını göstermektedir. Kıkırdak onarımı osteoblastları, kondroblastları, fibroblastları ve hematoprogenitor hücreleri subkondral kemik iliğinden hasarlı alana göç eden hücrelerin mobilizasyonuna bağlıdır. ${ }^{[7]} \mathrm{Bu}$ nedenle, ortaya çıkan onarım dokusu, çoğalan baskın hücre tipine, lokal büyüme faktörleri, sitokinler ve mekanik ortam ile modülasyonuna bağlı olarak değişken olabilir. Ayrıca kıkırdak onarımının ekleme ait doğal mekaniği sağlanamadığında iyileşmede başarısızlıklar ve kıkırdağın rejenerasyonunda azalma ile ilişkili olduğunu bildiren oldukça fazla sayıda çalışma bulunmaktadır. ${ }^{[8]}$ 

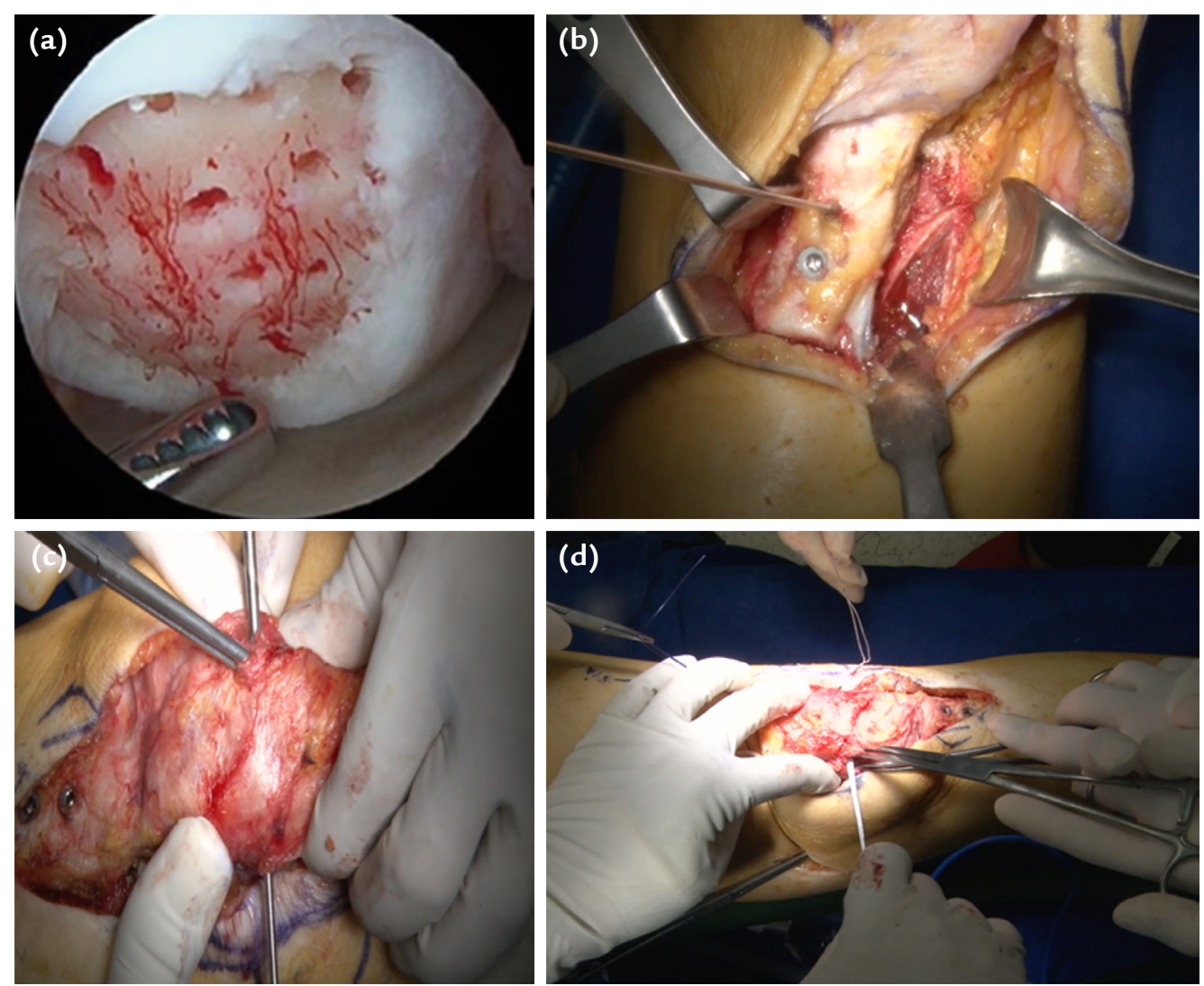

Şekil 1. a-d. Tanısal artroskopi esnasında medial femoral kondilde tespit edilen kondral hasarlı alana mikrokırık uygulanması (a), tüberositas tibia osteotomisi ve medializasyonunun uygulanması sonrası (b), patella diziliminin sağlanmasına yönelik medial patellofemoral bağ rekonstrüksiyonu için patellar tünelin hazırlanması (c), ve ardından osteotomi esnasında hastadan alınarak hazırlanan otogreftin patella ve femura tespiti (d).

\section{Kemik iliği Uyarıcı Teknikler (Abrazyon Kondroplasti, Mikrokırık ve Drilleme)}

Eklem kıkırdak hasarlarının iyileşmesini desteklemek için mezenkimal kök hücreleri kemik iliğinden serbest bırakmak amacıyla çeşitli prosedürler geliştirilmiştir. Bunlar arasında mikrokırık, abrazyon kondroplastisi ve subkondral delme işlemleri bulunmaktadır. Bu tekniklerin arkasındaki teori, kemik iliğinden defekt bölgesine kanama sağlayarak defekt üzerinde kan pıhtısı oluşturacak ve en sonunda fibrokartilaja dönüşecek ortamı sağlamaktır. Normal hiyalin kıkırdağını yeniden yaratan onarıcı bir süreç olmasa da, kusurlu doldurmayı ve defekti ortadan kaldırmayı amaçlamaktadır. Bu teknikler tipik olarak artroskopik olarak gerçekleştirilir ve daha sonra tartışılacak olan diğer biyolojik veya anatomik prosedürlere yardımcı olarak kullanılabilir. ${ }^{[9]}$ ilk olarak, kıkırdak hasarlı alan tüm hasarlı veya gevşek kıkırdaklardan arındırılmalıdır. Hasarlı bölgenin çevresi, kanın birikmesine izin vererek dik duvarlar oluşturacak şekilde hazırlanmalıdır. Kemik iliği stimülasyon tekniği uygulanmadan önce kalsifiye kıkırdak tabakasının çıkarılması zorunludur. Bu işlem pıhtının yapışmasına imkân sağlamaktadır. Mikrokırık tipik olarak dar bir biz kullanılarak gerçekleştirilir. İki ila dört milimetre derinliğinde ve üç ila dört milimetre aralıklarla delikler oluşturulur. ${ }^{[10]}$

Abrazyon kondroplastisi kıkırdak defektindeki subkondral kemiğin 1-2 mm derinlikte kazınması ile intraosseöz damarları açığa çıkarır, bu da kanamaya neden olur. Abrazyon kondroplasti subkondral kemiğin maruz kaldığı hasarların yüzeysel tedavilerini içermektedir. Burr veya küret ile defektin periferik alanlarını dahil etmek ve defekt kenarında omuzlanan kıkırdak tabakasını inceltmekten kaçınmak özellikle önemlidir. Yeterli rejenere kalınlık elde etmek için, büyük dejeneratif kusurların derinlemesine debridmanı gerekir.

Mikrokırık sonrası histolojik analizlerde düşük konsantrasyonlarda Tip II kollajen miktarı ile birlikte fibrokartilaj oluşumu olduğunu göstermiştir. Sonuçlar, 

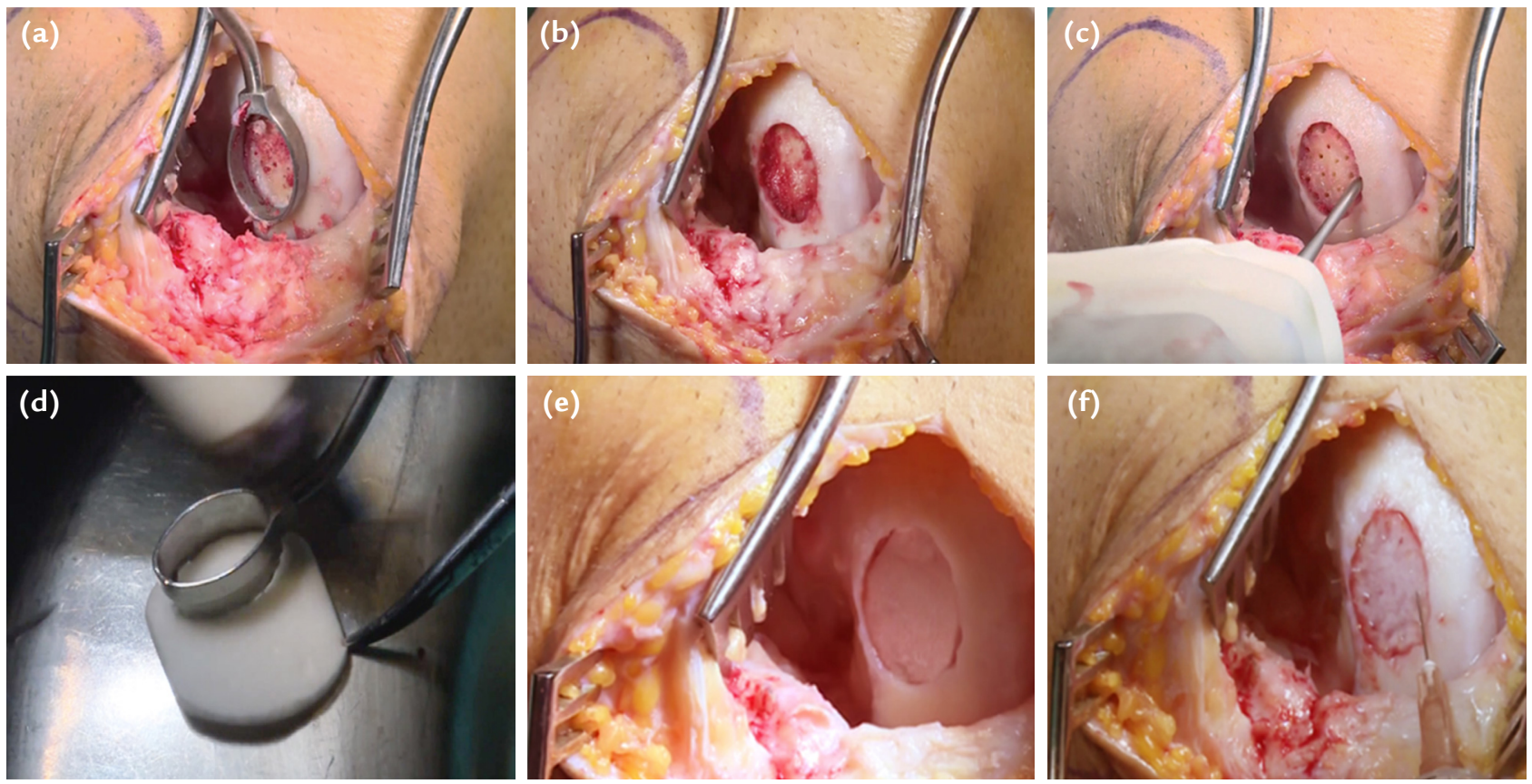

Şekil 2. a-f. Yüksek tibial osteotomi öncesinde medial femoral kondilde tespit edilen (a) kıkırdak hasarlı alana küretaj (b), mikrokırık (c) yapılması sonrası ölçüsünde kesilen kondral skafold (d) hazırlanan alana yerleştirilerek sağlam kıkırdak dokusuna sütüre edilmiştir (e). Stromal vasküler fraksiyon tekniği ile hazırlanan mezenkimal kök hücre membran altına uygulanarak (f) osteotomi sonrası kıkırdak rejenerasyonuna katkı sağlanmaktadır.

mikrokırığın küçük lezyonları $\left(<2 \mathrm{~cm}^{2}\right)$ olan genç hastalar için birincil tedavi olarak daha iyi kullanıldığını göstermektedir. Ağrı ve günlük yaşam aktiviteleri konusunda önemli iyileşmeler görülmüştür. Bununla birlikte, önceki atletik katılım seviyesine dönüşte bir azalma vardır. Bunun, oluşan fibrokartilaj tabakasının bozulmasının bir sonucu olduğu düşünülmektedir. Abrazyon kondroplastisine ait oldukça fazla sayıda kötü sonuçlar gösterilmiştir (Şekil 2). ${ }^{[10,11]}$

\section{Osteokondral Otogreft Transferi}

Osteokondral Otogreft Transferi (OOT), tam kusur boyutu, yeri ve cerrahın tercihine bağlı olarak artroskopik olarak veya açık bir yaklaşımla yapılabilir. Lezyon artroskopik olarak değerlendirilir ve hem donör hem de alıcı bölgeler için enstrümantasyonun eklem yüzeyine dikey olarak yönlendirilmesini sağlamak için spinal iğne ile aksesuvar portallar oluşturulur. Yatay deri kesisi ile oluşturulan portallar artroskopik bir yaklaşım için tercih edilir çünkü greftlerin dik yerleşimini sağlamak için bir portalın enine genişlemesine izin verir. Bazen transpatellar tendon yaklaşımı gerekebilir. Bu durumda, patellar tendon liflerine paralel bölünmeli ve prosedürün sonunda onarılmalıdır. illk olarak, defekti doldurmak için gereken greftlerin boyutunu ve sayısını belirlemek için boyutlandırma kılavuzları kullanılır. Daha sonra, uygun boyutta bir greft alıcı tüpü seçilir ve greft alıcının dik olarak sokulmasına dikkat ederek, yaklaşık 10-12 $\mathrm{mm}$ uzunluğunda bir osteokondral greft elde edilir. ${ }^{[12]}$ Diz eklemindeki birkaç bölgenin osteokondral greft için uygun olduğu tespit edilmiştir. Proksimal lateral troklear sırt, dizde daha az ağırlık taşıyan bir alan olarak kabul edilmesine rağmen, $40^{\circ}$ ila $70^{\circ}$ fleksiyonda patellofemoral eklemin önemli bir yük taşıyan kısmıdır ve bu bölgeden greft alınması halinde önemli semptomlara neden olabilir. Greft elde edildikten sonra, uzunluk ve herhangi bir potansiyel genişleme not edilir. Defektli alandan uygun boyutta ve açıda bir greft alıcı defekti çıkarmak için kullanılır ve yerleştirilecek greftin uzunluğundan yaklaşık $1 \mathrm{~mm}$ daha derin olduğundan emin olmak için derinlik cetvel ile kontrol edilir. Greft daha sonra greft tüpü içinde ilerletilir. Eklem yüzeyine dikey olarak yönlendirilir ve greft yavaşça alıcı bölgesine ilerletilerek yerleştirilir. Daha sonra greft alıcı çıkarlır ve greft tamamen oturtulur. İşlem kıkırdak defektli alanların tamamı için tekrarlanır.

Diz çevresi osteotomileriyle birlikte kolay uygulanabilir olması ile beraber klinik sonuçlarında ağrının azaldığı ve eklem fonksiyonlarının iyileştiği gösterilmiştir. Bu işlemlerin küçük veya orta boy tam kalınlık defektlerde ekstremite mekanik hizalanmasının doğala yakın düzeltilmiş olan olgularda en başarılı olduğu 
gösterilmiştir. OOT yapılan kıkırdak bölgesinin anormal yüklenmeye devam etmesi durumunda nakil greftin başarısız olmasına neden olabileceği literatürde sıklıkla vurgulanmaktadır. ${ }^{[12,13]}$

\section{Taze Osteokondral Allogreft}

Büyük osteokondral defektli, özellikle artroplasti veya artrodezi ertelemek isteyen daha genç, daha aktif hastalarda tercih edilmektedir. Osteokondral allogreftler (OKA), eklem mimarisinin düzeltilmesinde, hem eklem kıkırdağı hem de kemiğin ayrılmış olduğu osteokondritis dissekans lezyonları gibi büyük kusurlarının ortaya çıkması sonrası eklemin yeniden restore edilmesinde özellikle yararlıdır. OKA ihtiyacı, eklemin kritik kısımlarında, büyük boyutlu kıkırdak kusurlu eklemlerde ve kurtarma prosedürü gibi revizyon durumlarının tedavisi için yaygındır. ${ }^{[14]}$

Enfeksiyonun bulaşmasına ilişkin endişeler diğer allogreftlerle benzer olsa da, OKA transplantasyonu ile ilgili temel zorluk kondrosit canlılı̆ını korumaktır. ${ }^{[15]}$ Dondurulmuş dokunun aksine taze OKA materyalinin kondrositlerin canlılığını artırdığı yaygın olarak kabul edilmektedir. Ek olarak, vücut sıcaklığında depolamanın $4{ }^{\circ} \mathrm{C}$ 'deki ile karşılaştırıldığında kondrosit canlılığının değişimini gösteren laboratuvar çalışmaları yapılmıştır. Bununla birlikte, çoğu klinik çalışmada yaşayabilirliği uzatmak için dondurulmuş taze greftler kullanılmaktadır. Bir osteokondral greftin, greftin alınmasından hemen sonra ideal olarak implante edilmesi gerektiği yaygın olarak tespit edilmiş olsa da genellikle implantasyonun greftin tedarik edilmesinden sonraki 28 gün içinde yapılması gerektiği kabul edilmektedir. ${ }^{[16]}$ Uzun süreli saklama, doku içindeki kondrositlerin hayatta kalma oranını etkileyebilse de, birkaç çalışma, ortalama 28 günden daha uzun saklama süresine sahip implante edilmiş greftlerin aylar sonra hala klinik ve radyografik olarak başarılı olabileceğini göstermiştir.

Yakın zamanda yapılan kıkırdak biyokimyasal özelliklerinin karşılaştırmalı analizi, OKA'ların, tipik hastalıklı kıkırdak örneklerinden daha düşük seviyelerde proteoglikan tüketen metaloproteinazlar içerdiğini ve bu da greftlerin dayanıklılı̆ının bir moleküler işlemle ilişkili olabileceğini düşündürmektedir. ${ }^{[17]}$ OKA implantasyonu sırasında titiz cerrahi teknik başarılı bir sonuç için çok önemlidir. Saha hazırlığı ve aşırı delme veya çakma işleminin aşıı kullanımı ile implantasyon sırasında hem donör hem de alıcı kondrositlerde hücresel hasar veya ölüm meydana gelebilir. Bu komplikasyonu en aza indirmek için, kondrosit apopitozuna neden olacak kadar fazla darbelerden kaçınmak gerekmektedir. Greftin aşırı sıkışmasını önlemek ve hassas bir şekilde sabitlenmesini sağlamak için özellikler dikkat edilmesi gerekmektedir. Greft hazırlama, saklama ve cerrahi teknikteki
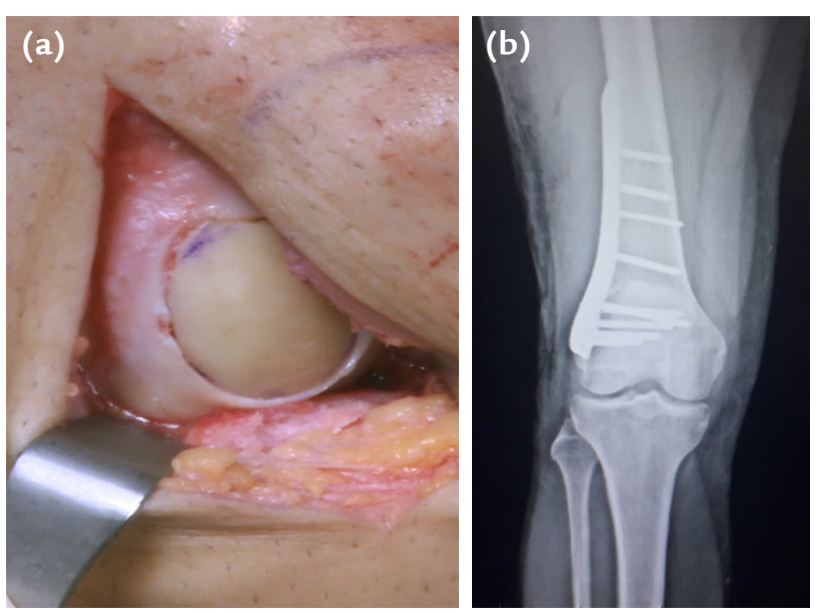

Şekil 3. a, b. Alt ekstremitesinde distal femurdan kaynaklanan valgus deformitesi tespit edilen hastada distal femur lateral açık kama osteotomi ile deformitenin düzeltilmesinden önce hasarlı lateral femoral kondile masif kondral allogreft hazırlanarak yerleştirildi (a), osteotomi sonrası alt ekstremite diziliminde düzelme ve lateral kompartmanda allogrefte ait görünüm izlenmektedir (b).

gelişmelere rağmen, OKA'ların transplantasyonu hala esas kurtarma prosedürü olarak kullanılmaktadır. OKA sonrası yüksek başarısızlık oranları kronik steroid kullanımı, çok büyük lezyonlar, daha önce yapılan çoklu ameliyatlar, vücut kitle indeksi $>26 \mathrm{~kg} / \mathrm{m}^{2}$, eklem uyumsuzluğu, bağ instabilitesi, inflamatuvar artropatiler, immün yetmezliği olan hastalar, menisküs yetmezliği, patellofemoral hastalık ve eklem anatomik diziliminde bozukluk olmasından kaynaklanmaktadır. Femoral kondil nakilleri en fazla başarıya sahiptir, başarısızık oranları $\% 0$ ile \%22 arasındadır. Bununla birlikte, bu çalışmaların çoğu standart dışı başarısızlık veya başarı tanımları, cerrahiyi başarısızık olarak gördükleri zaman çerçevesi, sınırlı takip ve az sayıda hasta ile sınırıdır (Şekil 3). ${ }^{18]}$

\section{Menisküs Tamiri ve Transplantasyonu}

Menisküs dokusunun kaybı sonucu özellikle total menisektomiden sonra, eklem kıkırdakları üzerindeki yükü \%200 ile \%300 arasında artırarak hem medial hem lateral bölmede diz ekleminin biyomekanik ortamını büyük ölçüde değiştirir. Bölgesel aşırı yüklenmeye bağlı olarak kronik ağrı ve tekrarlayan effüzyonlar ortaya çıkabilir. ${ }^{[19]}$ Sekonder osteoartrit, subtotal veya total meniskektominin kaçınılmaz olduğu durumlarda ortopedik cerrahlar arasında öngörülebilir bir son noktadır. Dikkatle seçilmiş hastalarda, menisküs tamiri veya menisküs allogreft transplantasyonu, gelişmiş biyomekanik ve fonksiyon sağlarken, aynı zamanda kıkırdak yapıların rejenerasyonuna katkı sağlamaktadır (Şekil 4 ve 5). ${ }^{[19]}$ 

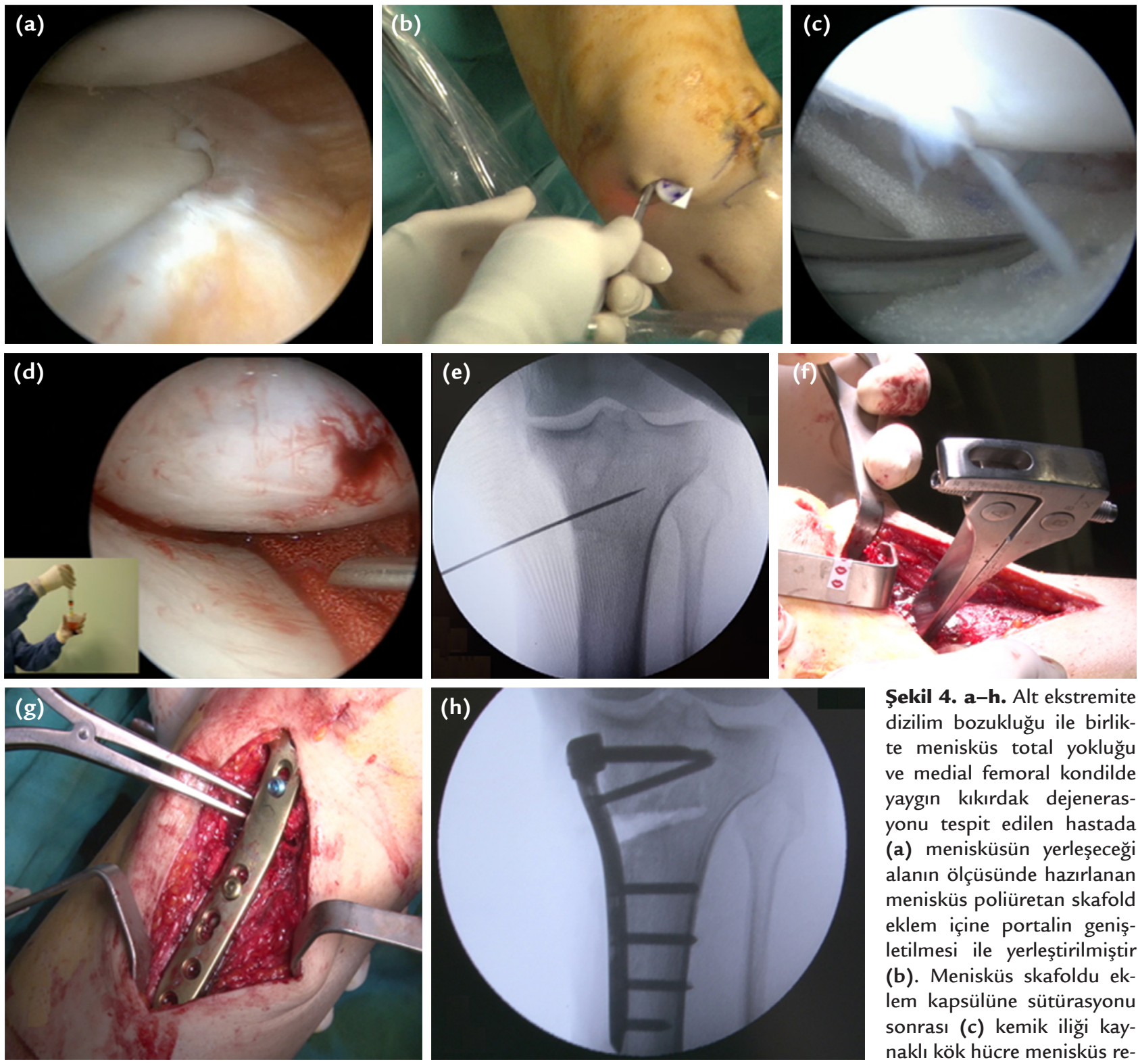

Şekil 4. a-h. Alt ekstremite dizilim bozukluğu ile birlikte menisküs total yokluğu ve medial femoral kondilde yaygın kıkırdak dejenerasyonu tespit edilen hastada (a) menisküsün yerleşeceği alanın ölçüsünde hazırlanan menisküs poliüretan skafold eklem içine portalin genişletilmesi ile yerleştirilmiştir (b). Menisküs skafoldu eklem kapsülüne sütürasyonu sonrası (c) kemik iliği kaynaklı kök hücre menisküs rejenerasyonunun sağlanması için skaffold ile eklem kapsülü arasına, kıkırdak rejenerasyonuna katkı sağlaması için eklem boşluğuna enjekte edilir (d). Kıkırdak rejenerasyonuna katkı sağlaması ve dizilimin sağlanması için yüksek tibial osteotomisi yapılmıştır (e-h).

\section{Kıkırdak Rejenerasyonunu Artırıcı Kök Hücre Uygulama Yöntemleri}

\section{Otolog kondrosit implantasyonu ve matriks rehberli otolog kondrosit implantasyonu}

Hücre bazlı tedavileri üç kuşak olarak değerlendirebiliriz. Birinci kuşak tedaviler; kültüre edilmiş otolog hücrelerin defekt alanına yerleştirilip, otolog periostal örtü ile kapatılmasını içeren Otolog kondrosit implantasyonudur (ACl-P). ACl hakkında ortaya konan birçok iyi rapora rağmen cerrahi teknikteki zorluklar, oldukça invaziv olması, maliyet ve özellikle periostal örtüye bağlı komplikasyonlar nedeniyle kollajen örtülerin kullanıldığı ikinci kuşak tedaviler diyebileceğimiz kollagen kaplı otolog kondrosit implantasyonu (ACl-C) tekniği tanımlanmıştır. İkinci kuşak bu tedaviler, birinci kuşak tedaviler ile benzer sonuçlar vermekteydi ve hipertrofi komplikasyonu devam etmekteydi. Ortaya çıkan yenilikler, temel bilimlerdeki ilerlemelerle birlikte tüm bu sorunlara çözüm bulmak amacıyla üç boyutlu biyobozunur 

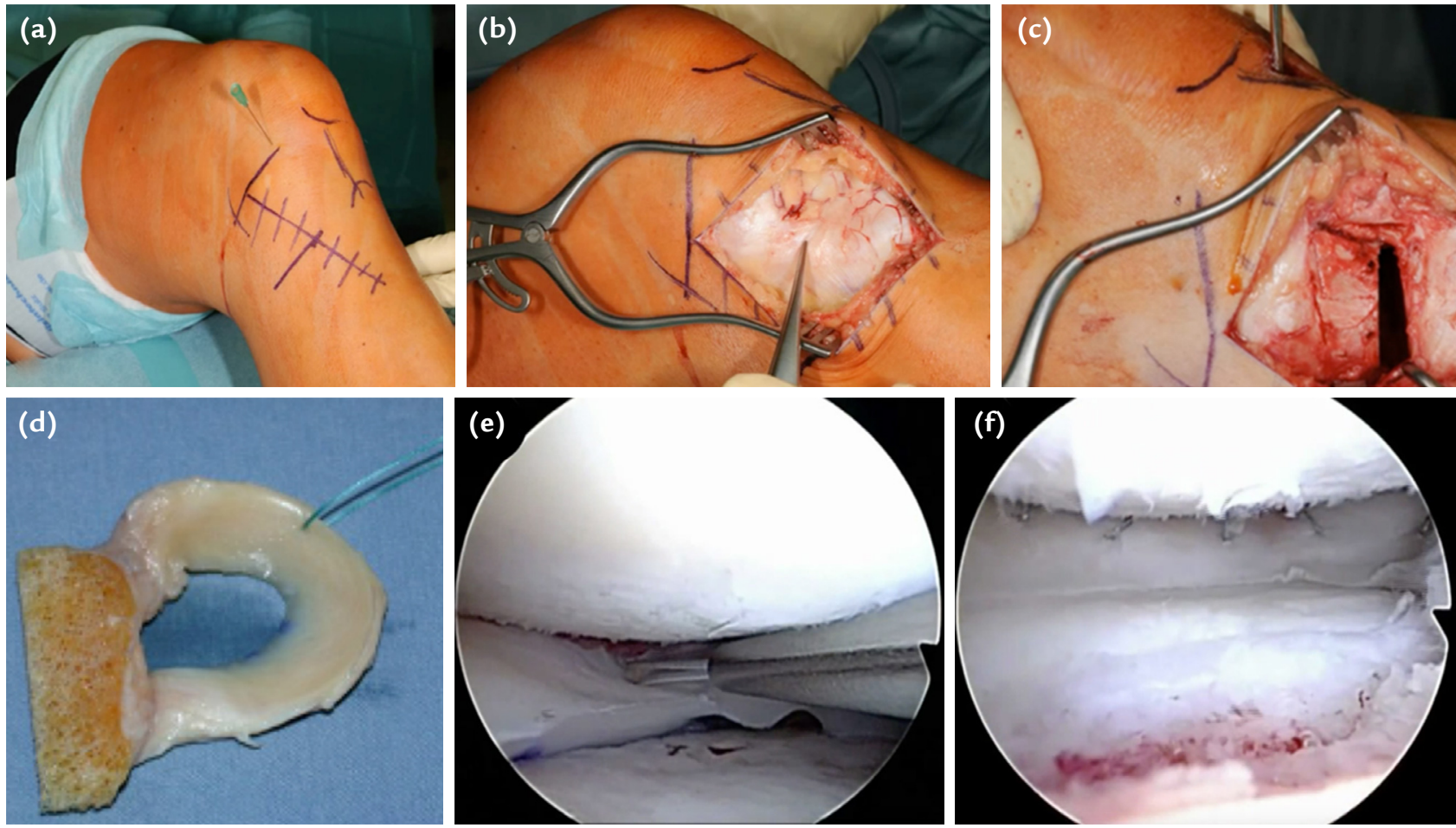

Şekil 5. a-f. Geçirmiş olduğu total medial menisektomi sonrası medial eklem aralığında daralma, medial femoral kondilde kıkırdak dejenerasyonu tespit edilen hastada eklem diziliminin sağlanması için medial açık kama yüksek tibial osteotomisi yapıldı (a-c). Kıkırdak rejenerasyonuna katkı sağlaması için menisküs allogreft ile menisküs tamiri gerçekleştirilmiştir (d-f).

çatıların kullanıldığı üçüncü kuşak tedaviler olan matriksle indüklenmiş otolog kondrosit implantasyonu (MACl) tekniği tanımlanmıştır. ${ }^{[20]}$

Otolog kondrosit implantasyonu (ACI); birinci (ACI-P) ve ikinci jenerasyon (ACl-C): Otolog kondrosit implantasyonu (ACI) ilk kez 1987 yılında uygulanmıştır. Hücre imalâtı için otolog kıkırdağın kullanılması esasına dayanır. Eklem kıkırdağının innervasyonu yoktur; aynı zamanda avasküler ve alenfatiktir. Kondrositlerin beslenmesi ise pasif diffüzyon ile gerçekleşmektedir. Erişkinlerin eklemindeki hiyalin kıkırdakta bulunan tek hücre tipi kondrosittir ve kıkırdak dokunun \%2 ila \%5'ini oluşturmaktadır. ${ }^{[21]}$ Kondrositler ekstrasellüler matriksin yapımı ve remodelasyonundan sorumludur. Hiyalin kıkırdak kendi kendini yenileme yeteneğinden yoksun proteoglikanlar ve Tip II kollajen ve az bir miktarda elastinden oluşan son derece organize bir dokudur. ${ }^{[22]}$ Tam kat kıkırdak defektleri yıllarca hastanın kondrosit kültürlerinden elde edilen hücrelerin bir membran altına yerleştirilmesi şeklinde iki aşamalı olarak tedavi edilmekteydi. Hastanın kendisinden temin edilen periost tabakası dışta fibroblastlardan oluşan "fibroz tabaka" ile içte osteojenik progenitör hücreler içeren “kambiyum tabakasından"meydana gelmektedir. Bu nedenle osteojenik kapasiteye sahiptir. Kondrotropik ortamda aynı zamanda kıkırdak oluşumunu teşvik etmek için de kullanılabilir. Periost kullanımı su geçirmez bir ortam sağladığından defekte yerleştirilen kondrositlerin defekt sınırları içerisinde kalmasına olanak sağlamaktadır. ACl'da ilk basamak biyopsi aşamasıdır. Biyopsi için standart artroskopi seti ve yuvarlak bir küret yeterlidir. Artroskopi öncesi hücre kültürü yapacak laboratuvar biyopsi hakkında bilgilendirilmelidir. Artroskopi sırasında defekt tanımlanır ve boyutları ölçülür. Yapılan artroskopik işlemde yapılanlar ve tüm patolojik yapılar ayrıntılı kayıt edilir. Kıkırdak biyopsisi eklemin az yük binen alanlarından yapılmalıdır. ${ }^{[23]}$ Medial femoral kondilin üst kısmı, trokleanın superior medial kenarı veya interkondiler notch uygun yerlerdir. $1 \mathrm{~cm}$ uzunluk ve $0,5 \mathrm{~cm}$ genişlikte tam kat kıkırdak örneği alınmalıdır. Biyopsi alırken kıkırdakkemik birleşim yerinin derinine inilmelidir. İki-üç örnek almak yeterlidir. Kıkırdak örneği laboratuvara gönderildikten sonra kondrositler izole edilip 2-3 haftalık sürede çoğaltılır. Çoğaltılan hücreler hekime süspansiyon halinde geri gönderilir. İkinci basamak açık cerrahi aşamasıdır. Mini artrotomi ile gerçekleştirilir. 
Kıkırdak defekti debride edilir. Debritman sonrası defekt iyi şekillendirilmiş olmalıdır. Defekt boyutları ölçülür. Kanama olursa defekt tabanı epinefrin (1:100 epinefrin $20 \mathrm{~mL}$ saline katılarak) emdirilmiş pamuklar ile tamponlanır. Defekt; periost (birinci jenerasyon: $\mathrm{ACl}-\mathrm{P}$ ) veya kollajen membran (ikinci jenerasyon: $\mathrm{ACl}-\mathrm{C}$ ) ile örtüldükten sonra, hücreler defekt içine enjekte edilir. Birinci jenerasyonda periost dokusu; pes anserinusun hemen distalinden, tibia proksimalinin medialinden alınır. Periostun kambiyum tabakası defekte bakacak şekilde eriyebilen ipler kullanılarak periost, defekt kenarındaki sağlam kıkırdağa dikilir. Hücre kaybını azaltmak için dikiş yerleri fibrin yapıştırıcı ile kapatılır. Hücreler membranın altına enjekte edilir. Amaç $\mathrm{mL}^{\prime}$ 'de 30 milyon veya $\mathrm{cm}^{2}$ 'de 2 milyon hücre implante etmektir. Defektin duvarları sağlam değil ise membranı dikmek için ankor kullanılabilir veya mozaikplasti greft alıcıları ile de duvar oluşturulabilir. İkinci jenerasyonda kollajen membran tam defekt boyutunda kesilmelidir; çünkü periost kadar esneyemez. Hastada eşlik eden dizilim bozukluğu da varsa artrotomi sırasında defekt hazırlandıktan sonra yükten kurtarıcı diz çevresi osteotomi yapılır, en son hücreler implante edilir. ${ }^{[24]}$

ACI-P ile hastaların çoğunda klinik rahatlama elde edilmesine rağmen, kondroproliferasyonun sürekli devam etmesi nedeniyle kıkırdak seviyesinden daha fazla hipertrofi meydana geldiği ve bu nedenle aralıklarla artroskopik olarak traşlanması gerektiği bildirilmiştir. Bu komplikasyon nedeni ile genellikle çift katlı membran tabakasından oluşan, Tip I ve Tip III kollajenden zengin membranlar kullanılmaktadır ( $\mathrm{ACl}-\mathrm{C})$. Düzgün ve yumuşak yüzey hücrelerin diffüzyonuna engel olurken; porotik yüzey hücrelerin proliferasyonuna izin veren bir zemin oluşturmaktadır. Ortalama 24 haftada rezorbe olması, bu nedenle hipertrofi komplikasyonunda azalma olması ve hastaya periost temin edilmesi esnasında yapılan ek cerrahi insizyon gerektirmemesi morbiditede azalma sağlamaktadır. ${ }^{[25]}$

Gooding ve ark. ${ }^{[26]}$ tarafindan periost ve kollajen membranın kullanımını karşılaştıran ileriye dönük randomize klinik çalışmada tam kat kondral hasara sahip hastalara $\mathrm{ACl}-\mathrm{P}$ veya $\mathrm{ACl}-\mathrm{C}$ uygulanmış sonrasında iki yıl hastalar takip edilmiş, fonksiyonel ve klinik sonuçlar değerlendirilmiştir. ACI-C ile \%74, ACI-P ile de \%67 mükemmel sonuç elde etmişler ve iki teknik arasında anlamlı fark olmadığını tespit etmişlerdir. Birinci yıl sonunda tekrar artroskopik cerrahi girişim gereksinimi ACI-P uygulanan hastaların \%36,4'ünde gerekli görülürken, $\mathrm{ACl}-\mathrm{C}$ uygulanan hastaların ise hiçbirinde bu gereksinime ihtiyaç duyulmamıştır. Sonuç olarak hipertrofi ve tekrarlayan artroskopiler nedeniyle kollajen membran kullanımını önermişlerdir. Briggs ve ark., yapmış oldukları çalışmada $\mathrm{ACl}-\mathrm{C}$ yapılan hastaların hiçbirinde ektopik kalsifikasyona rastlamadıklarını bildirmişlerdir. İ vitro çalışmalarda ACI-P yönteminde tamir dokusu içindeki düzensiz proteinaz ekspresyonunun, hipertrofi veya periost greft reddine yol açabileceği gösterilmiştir. [26]

Periost hasta ile biyolojik açıdan uyumlu, maliyet gerektirmeyen, hücre ve büyüme faktörleri için iyi bir kaynak olsa da; ek insizyona bağlı artan morbidite, bu nedenle uzamış hastanede kalış süresi ve enfeksiyon riskinde artış gibi dezavantajlara sahiptir. Ayrıca periostun mezenkimal aktivitesi hastadan hastaya ve uygulanan cerrahi tekniğe bağlı olarak değişebilmektedir. Kollajen membranların ise daha standart sonuçlarının olması, ek insizyon gerektirmemesi, kısa ameliyat süresi ve azalmış morbidite gibi avantajları varken; artmış maliyet dezavantajı bulunmaktadır. Kollajen mebranlar daha az esnek olsa da, dikiş ve taşıma esnasında yırtılma olasılıkları periosta göre daha düşük düzeylerdedir (Şekil 6).

Matriks rehberli otolog kondrosit implantasyonu (MACI) üçüncü jenerasyon: Teknolojik gelişmeler ve yeni biyomateryallerin üretilmesi sonucu 3. nesil kondrosit transplantasyon teknikleri ortaya çıktı. "Hepsi bir arada" kompozit doku mühendisliği yaklaşımı sayesinde; biyouyumlu çatı implantları (skaffold) ile kültüre kondrositler birleştirilmiştir. Hücre içerikli skaffoldların defektif bölgeye uygulanması esnasında artrotomi dışında ek insizyon gerektirmemesi, defektin boyutuna göre kesilerek şekillendirilebilmesi, dikiş gerektirmemesi ve gerek görülürse fibrin yapıştırıcılar ile kullanılabilmesi teknik kolaylık sağlamaktadır. Üçüncü kuşak kondrosit transplantasyonu amacıyla in-vivo ve invitro olarak test edilerek geliştirilen birçok biyotaşıyıcı materyal mevcuttur (Tablo 1). ${ }^{[27]}$

Genellikle domuz kaynaklı Tip I-III kollajen membranlara kondrositlerin laboratuvar ortamında (2. jenerasyonda olduğu gibi cerrahi alanda değil) homojen olarak inoküle edilmesi ile cerrahi gerçekleştirilir. MACI 2. jenerasyon kollajen örtülü otolog kondrosit implantasyonundan ( $\mathrm{ACl}-\mathrm{C})$ geliştirilmiştir. Hücreler implantasyondan üç gün önce membrana emdirilir. Greft, hücreler defekte bakacak şekilde fibrin yapıştırıcı ile defekte yerleştirilir. Kendine has avantajları vardır. Dikiş tespiti gerektirmez, hücre kaçağı olmaz ve kolay şekil verilebilir. Diğer iki kuşağın aksine hücreler homojen dağılmıştır. Her ne kadar kıkırdak rejenerasyonu tedavilerinde etkin olsada 18-50 yaş, 4-14 cm² (Grade 3-4) kondral hasarlarda ve daha önce denenmiş tekniklerden yarar görmemiş olgularda 2. basamak tedavilerde endikedir. İnstabilite, dizilim bozukluğu, enfeksiyon, inflamatuvar hastalık, bipolar (kissing) lezyon, dejeneratif artrit ve ilgili kompartmanda total menisektomi durumlarında kullanılması önerilmez. ${ }^{[28]}$ 

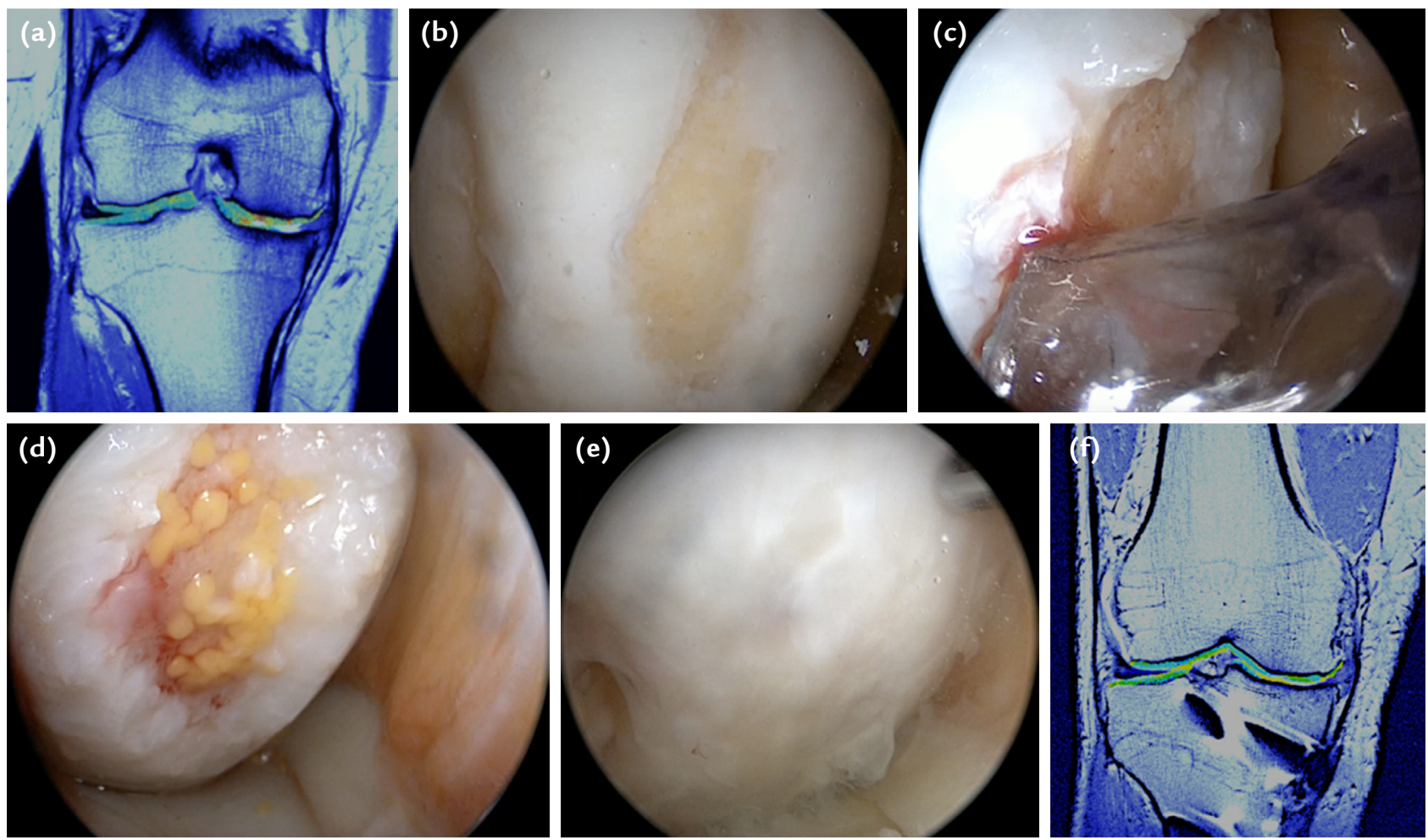

Şekil 6. a-f. Medial femoral kondilde subkondral tabakayı içeren kıkırdak hasarı ve alt ekstremitede varus deformitesi (a) tanısı ile artroskopik abrazyon kondroplastisi (b) yapılmasını takiben otolog kondrositler defektli alana ekilerek (c, d) yüksek tibial osteotomisi yapılan hastanın ameliyat sonrası 1. yılda tanısal artroskopisi (e) ve MR görünümü (f).

Tablo 1. Jenerasyonlara göre kondral hücre süspansiyonları[ ${ }^{[27]}$

\begin{tabular}{|c|c|c|}
\hline Teknik & Ürün & Marka/Firma \\
\hline \multicolumn{3}{|c|}{ 1. JENERASYON: Periost ile birlikte uygulanabilen hücre süspansiyonları } \\
\hline & ACT-Biotissue & Biotissue \\
\hline & Carticel & Genzyme \\
\hline & ChondroCelect & Tigenix \\
\hline & Chondrotransplant & Codon \\
\hline & Novocart & Tetec \\
\hline \multicolumn{3}{|c|}{ 2. JENERASYON: Hücre süspansiyonu ile birlikte kollajen membran } \\
\hline & Artrocell & Cellgenix/Geistlich/Ormed \\
\hline & $\mathrm{CACl}$ & Verigen \\
\hline \multicolumn{3}{|c|}{ 3. JENERASYON: Hücre-Biyomateryal } \\
\hline Hyaluronan Polimer & Hyalograft & $\mathrm{FAB}$ \\
\hline Kollagen-Jel & CaRes & Ars Arthro \\
\hline \multirow[t]{3}{*}{ Kollagene Membran } & ArthtoMatrix & Arthrex/Orthogen \\
\hline & $\mathrm{MACl}$ & Verigen/Genzyme \\
\hline & MACT & Igor/Andrê \\
\hline \multirow[t]{2}{*}{ Polimer } & Bioceed-C & BioTissue \\
\hline & Novocart3D & Tetec \\
\hline
\end{tabular}


íkinci jenerasyonda kullanılan kollajen tabakaların kullanımının geliştirilmesi ve bunlara kültüre edilen kondrositlerin bağlanması ile geliştirilen tekniklerin başında membran bağlı kondrosit implantasyonu olarak bilinen, başarısı kanıtlanmış bir yöntem olarak $\mathrm{MACl}$ gelmektedir. $\mathrm{ACl}-\mathrm{P}$ ve $\mathrm{ACl}-\mathrm{C}$ tekniklerinin uygulanması ile ilgili doğal sorunlar mevcuttur. ${ }^{[29]}$ Su geçirmez bir alan oluşturarak hücrelerin defektli alanda kalmasını sağlamak oldukça güçtür. Düzensiz lezyonlarda osteokondral kavşaklara ve kenarlara kondrositlerin ulaşımı ile ilgili sıkıntılar mevcuttur. Hücrelerin membran altında homojen dağılmaması ve sağlam kıkırdağa dikilmesi ile ilgili güçlükler ACI-P ve ACl-C'yi oldukça zor uygulanır hale getirmektedir. Membranların sağlam kondral tabakaya sütürasyonu için daha büyük artrotomi insizyonlarına gereksinim duyulması da bu tekniklerdeki morbiditeyi artıran bir başka unsurdur. $\mathrm{MACl}$; yapışkan özelliği ve homojen hücre dağılımı ile osteokondral kavşaklarda rahatlıkla implante edilebilir. ${ }^{[27]}$

Bartlett ve ark., ortalama lezyon büyüklüğü $6 \mathrm{~cm}^{2}$ olan $44 \mathrm{ACl}-\mathrm{C}$ yapılan hasta ile $47 \mathrm{MACl}$ yapılan hastanın bir yıllık sonuçlarını karşılaştırmış ve her iki grubun sonuçları arasında anlamlı bir fark olmadığı sonucuna ulaşmışlardır. ${ }^{[30]}$ Yapmış oldukları benzer bir çalışmada ortalama lezyon büyüklüğü $4,1 \mathrm{~cm}^{2}$ olan iki grup hastaya $\mathrm{ACl}-\mathrm{P}$ ve $\mathrm{MACl}$ uygulamış ve iki yıllık sonuçları karşılaştırmışlar, uluslararası diz dokümantasyon komitesi (IKDC) puanı, Tegner aktivite skoru ve kısa form 36 puanını her iki grupta da benzer bulmuşlardır. Manyetik rezonans (MR) görüntüleme çalışmasında ise cerrahi sonrası 6 . ayda MCART (Magnetic Resonance Observation of Cartilage Repair Tissue) skorunda MACI ve ACI-P arasında anlamlı fark bulunduğu fakat bu farkın 12. ve 24. aylarda ortadan kalktığı tespit edilmiş̧ir. Bu her iki çalışma benzer sonuçlar gösterse de; grupların küçük olması, uzun süreli takip sonuçlarının olmaması ve defektlerin orta boyutlu olması gibi zayıf yönleri bulunmaktadır. ${ }^{[30]}$

Literatürde rehabilitasyon ve spora dönüş açısından $\mathrm{ACl}-\mathrm{P}, \mathrm{ACl}-\mathrm{C}$ ve $\mathrm{MACl}$ yöntemlerini karşılaştıran çok fazla yayın olmamasına rağmen Seviye I ve Seviye II birkaç yayının ortak sonucu: $\mathrm{ACl}-\mathrm{C}$ 'nin $\mathrm{ACl}-\mathrm{P}$ 'ye üstün olduğu ve MACl'nin her iki yönteme karşı daha hızlı spora dönüş sağladığı yönündedir.

\section{Kemik iliği ve yă̆ dokusu kaynaklı mezenkimal kök hücre uygulamaları}

Kök hücre uygulamalarının ortopedi ve travmatolojide temel uygulama alanlarından birisi de eklem kıkırdak hasarlarının biyolojik tedavisidir. Genç hastalarda fokal, semptomatik kıkırdak lezyonları oldukça yaygın görülen bir problemdir. Ağrı, şişlik, eklemde kilitlenme, sertlik ve ses gelmesi kıkırdak lezyonlarının yaygın görülen semptomlarıdır ve bu semptomlar; kişinin çalışmasını ve spor yapmasını engelleyebildiği gibi, günlük aktivitelerini de kısıtlayabilir. Konvansiyonel teknikler ile tedavi sonrası fonksiyonların geri kazandırılması her zaman sağlanamamakta ve eklem artroplastisi ile özellikle genç hastalarda tatmin edici sonuçlar almak mümkün olmamaktadır. ${ }^{[31]}$ Kıkırdak hasarlarının tedavisine yönelik olarak sıkça kullanılan mikrokırık gibi kemik iliği stimülasyon teknikleri sonucu fibröz kıkırdak elde edilmektedir. Uygulanan tedavi sonrası hiyalin kıkırdak elde edilebilen otolog osteokondral transplantasyon ve otolog kondrosit implantasyonu gibi teknikler geliştirilmiş ve güncel tedavi yaklaşımları arasında yer almaktadır. Kök hücre tedavisinin kullanımı, defekt içerisinde hiyalin kıkırdak oluşturmayı amaçlayan heyecan verici, alternatif bir stratejidir. Bu yeni oluşan hiyalin benzeri kıkırdak, defekti çevreleyen normal kıkırdak ile entegre ve mekanik olarak işlevsel olabilecektir. Kök hücreler, kendiliğinden daha fazla sayıda kök hücre oluşumuna sebebiyet verebilen yenilenme ve uygun koşullar altında çeşitli doku türlerine farklılaşma kapasitesine sahip olmalıdır. ${ }^{[32]}$ Kök hücre türüne bağlı olarak, pluripotent veya multipotent olabilir. Mezenkimal kök hücrelerin (MSCs) kıkırdak, tendon ve kemik hücrelerine iyi diferansiyasyon kapasiteleri göstermeleri nedeniyle bu dokularda umut verici sonuçlar elde edilmiştir. Mezenkimal kök hücreler kemik iliği, yağ, sinovyal membran, periost ve daha birçok farklı mezenkimal dokudan izole edilebilir. Ayrıca bu hücreler izole edildiği dokulara göre farklı diferansiyasyon kapasitelerine sahiptir.

Mezenkimal kök hücreler, retiküler hücreler, adipositler, osteojenik hücreler, düz kas hücreleri, endotelyal hücreleri ve makrofajları da içeren postnatal kemik iliği stromasında bulunur. ${ }^{[33]}$ Mezenkimal kök hücreler ayrıca yağ, deri ve periosteum gibi farklı dokulardan izole edilebilir. Bu multipotent hücrelerin kıkırdak, kemik, kas, tendon, bağ ve yağ gibi dokulara farklılaşma kabiliyeti vardır. Mezenkimal kök hücrelerin bu birçok kas iskelet dokusuna farklılaşma yeteneği, kemik ve kıkırdak tamir ve rejenerasyonu için büyük bir potansiyel taşımaktadır. Bu durum bilim adamlarına, istenilen biyolojik ve mekanik özeliklere sahip, uygun dokuların oluşturulması için bu hücrelerin üzerinde çalışma imkânı yaratmıştır. Bu hücrelerin, uygun koşullar altında yüzey belirteçleri ile karakterize edilen, kemik, kıkırdak, kas ve yağ hücrelerine farklılaşması indüklenebilir. ${ }^{[34]}$

Farklı hücre tiplerine farklılaşabilen benzersiz yeteneği yanı sıra, mezenkimal kök hücrelerin, sekrete ettiği farklı sitokinler ile anti-inflamatuvar aktivite gösterdiği ve anabolik bir mikro çevre oluşturduğu bulunmuştur. 
Kök hücreler iki farklı yol ile kullanılabilir. Birincisi hücre terapisi olarak isimlendirebileceğimiz kök hücrelerin izole edilip direkt "hücre" olarak uygulanmasıdır. Kemik iliğinin aspire edilmesinin ardından kök hücreler ayrıştırılarak doğal olarak kullanılabilir veya hücreler ayrıştırılır ve laboratuvar ortamında kültüre edilerek sayıları artırılarak kullanılır. Kök hücrelerin diğer kullanım şekli ise daha karmaşık ve uğraş gerektiren doku mühendisliğidir. ${ }^{[35]}$

Burada hücreler üç boyutlu matriksler ile doku benzeri yapılar oluşturularak doku veya tüm organ olarak kullanılabilirler. Geçtiğimiz 10 yıl içerisinde doku mühendisliği alanında yapılan temel bilimler çalışmaları ile birçok farklı doku yapısının kompozisyonu in-vitro olarak oluşturulabilmiştir. Son on yıl içinde, doku mühendisliği alanında pek çok bilim adamı damarlanma problemini çözmeye odaklanmıştır. Ancak, insanlarda büyük katı doku veya hatta tüm organın doku mühendisliği için uygulanabilirliğini kanıtlayan çabaların şimdiye kadar kesin olarak başarıya ulaştığı söylenemez. ${ }^{[31,35]}$

\section{Kıkırdak Rejenerasyonunu Artırıcı Büyüme Faktörlerinin Kullanımı}

\section{Transforme edici büyüme faktörü ailesi (TGF-ß)}

Kıkırdak onarımında, TGF- $\beta$ süper ailesinin en iyi incelenen üç üyesi TGF- $\beta 1$, kemik morfogenetik protein-2 (BMP-2) ve kemik morfogenetik protein-7'dir (BMP-7). TGF- $\beta 1$ 'in kondrosit sentetik aktivitesini uyardığı ve IL1 'in katabolik aktivitesini azalttı̆̆ı bildirilmiştir. BMP'ler kemik ve kıkırdak gelişiminde önemli bir rol oynar. ${ }^{[36]}$ TGF- $\beta$ sinyal yoluna ve sitokin-sitokin reseptör etkileşimine katılırlar. Hayvan çalışmaları BMP-2'nin kıkırdak matris üretimini artırdığını ve IL-1 ile indüklenen kıkırdak dejenerasyonunu bloke ettiğini göstermiştir. BMP7, kıkırdak onarımı için bir başka altın standart büyüme faktörüdür. BMP-7'nin hücre proliferasyonunu inhibe ettiği, ancak hem sinovyal kökenli kök hücreler (SKKH) hem de kemik iliği kaynaklı mezenkimal kök hücrelerde (KMKH) ekstrasellüler matriks (ESM) sentezini uyardığı bildirilmiştir. ${ }^{[37]}$

\section{Insülin benzeri büyüme faktörü-1 (IGF-1)}

IGF-1 çok fonksiyonlu bir büyüme faktörüdür. Çalışmalar, IGF-1'in eklem kıkırdak bütünlüğünün korunmasında önemli bir rol oynadığını bulmuştur. IGF-ı eksikliği eklem lezyonlarının gelişmesine yol açmıştır. IGF-1 sadece proteoglikanların sentezini artırmakla kalmaz aynı zamanda kollajen II'nin gen ekspresyonunu düzenler, aynı zamanda matris metallopetidaz-13 (MMP-13) üretimini azaltarak hücre dışı matrislerin bozulmasını da azaltabilir. Araştırma, IGF-1'in bu fonksiyonları doza bağlı bir şekilde yerine getirdiğini göstermiştir. Düşük doz IGF-1, serumdaki kemik oluşum belirteçlerini artırarak kemik yeniden şekillenmesi üzerinde yararlı bir etkiye sahiptir. Osteoartrit (OA) osteoblastlarında daha yüksek IGF-1 seviyeleri kemik sklerozu ile ilişkili olabilir. ${ }^{[38,39]}$

\section{Fibroblast büyüme faktörü (FGF)}

Kıkırdak rejenerasyonunda kullanılan iki FGF üyesi vardır. Bunlardan birine temel FGF (bFGF) veya FGF2, diğerine FGF-18 denir. FGF-2, kıkırdakta anabolik malzeme seviyelerini artırır ve agrekanaz seviyelerini azaltır. In vivo çalışma, bFGF'nin kıkırdak onarımını teşvik edebileceğini göstermiştir. Bununla birlikte, bazı çalışmalarda, OA hastalarının sinovyal sıvı örneklerinde FGF-2 konsantrasyonu normal sağlıklı diz eklemlerinin yaklaşık iki katıdır. Daha ileri çalışmalar, FGF2'nin olgunlaşmamış tavşanlarda artiküler kıkırdağın kısmi kalınlık kusurlarının onarımını teşvik ettiğini, ancak olgun tavşanlarda olmadığını buldu. Bir sıçan modeli çalışması, FGF-18'in kondrogenezi ve kıkırdak onarımını konsantrasyona bağlı bir şekilde uyardığını göstermiştir. Daha fazla çalışma, FGF-18'in osteoartrit için terapötik bir ajan olabileceğini göstermiştir. Kıkırdak yaralanması tedavisinde rekombinant bir insan FGF-18 formu kullanılmıştır. ${ }^{[40,41]}$

\section{Platelet zengin plazma (PRP)}

Trombositler hemostazda temel bir rol oynar ve doğal bir büyüme faktörü kaynağıdır. PRP'de 30'dan fazla büyüme faktörü tanımlanmıştır; aralarında, aşağıdaki altı büyüme faktörü kıkırdak rejenerasyonunda önemli bir rol oynamaktadır. TGF- $\beta 1$, trombosit türevli büyüme faktörü (PDGF), fibroblast büyüme faktörü (FGF), insülin benzeri büyüme faktörü 1 (IGF-1), epidermal büyüme faktörü (EGF) ve vasküler endotelyal büyüme faktörüdür (VEGF). Kıkırdak onarımı için kullanılan PRP'deki trombosit konsantrasyonu, taban çizgisinden iki ila üç kat daha yüksek olmalıdır. PRP aşağıdaki beş prosedürle hazırlanabilir. ${ }^{[42]}$ Bir santrifüj tüpü içinde $\% 3,8$ sodyum sitrat çözeltisine kan eklenir ve üç tabaka elde etmek için beş dakika boyunca 500 g'de santrifüjlenir. Üst katmandaki süpernatan, trombosit içeren plazma olarak adlandırılan yeni bir tüpe aktarılır ve orta katman, lökosit içeren plazma olarak adlandırılan başka bir yeni tüpe aktarılır. Trombosit içeren plazma ayırmak için 2000 g'de beş dakika santrifüjlenir. Trombosit peleti saf PRP yapmak için uygun miktarda süspanse edilir. Lökosit içeren plazma, trombosit peleti ile karıştırılır ve lökosit içeren PRP (L-PRP) yapmak için uygun miktarda yeniden süspanse edilir. Hem P-PRP hem de L-PRP, kıkırdak doku mühendisliği ve kıkırdak rejenerasyonu için kullanılabilir. ${ }^{[42,43]}$ 


\section{SONUÇ}

Kıkırdak rejenerasyonunun artırılmasına yönelik kıkırdak doku mühendisliği, özel koşullar altında yeni kıkırdak üretmek için biyomateryal iskele, biyoaktif moleküller ve hücreler kullanmaktır. Malzeme bilimi, yaşam bilimi ve mühendisliğindeki hızı ilerleme, özellikle kıkırdak kusurları olmak üzere çeşitli hastalık ve hastalıkların tedavi seçeneklerinde ilerlemelerle sonuçlanmıştır. Bununla birlikte, kıkırdak mühendisliği ve kök hücre tedavilerindeki gelişmeler ışığında zor görülen kıkırdak doku tedavilerine olumlu yanıtlar alınmaktadır. Kıkırdağın rejenerasyonunun sağlanması esnasında ekleme ait yük dağılımının ve dizilimin iyi bir şekilde ayarlanması rejenerasyon sürecine katkı sağlayacaktır.

\section{KAYNAKLAR}

1. van Wulfften Palthe AFY, Clement ND, Temmerman OPP, Burger BJ. Survival and functional outcome of high tibial osteotomy for medial knee osteoarthritis: a 10-20-year cohort study. Eur J Orthop Surg Traumatol 2018 28(7):1381-9. Crossref

2. Franceschi F, Longo UG, Ruzzini L, Marinozzi A, Maffulli $N$, Denaro V. Simultaneous arthroscopic implantation of autologous chondrocytes and high tibial osteotomy for tibial chondral defects in the varus knee. Knee 2008 15(4):309-13. Crossref

3. Willinger L, Lang JJ, von Deimling C, Diermeier T, Petersen W, Imhoff $A B$, Burgkart R, Achtnich A. Varus alignment increases medial meniscus extrusion and peak contact pressure: a biomechanical study. Knee Surg Sports Traumatol Arthrosc 2019. Crossref

4. Osano K, Nagamine R, Todo M, Kawasaki M. The effect of malrotation of tibial component of total knee arthroplasty on tibial insert during high flexion using a finite element analysis. ScientificWorldJournal 2014;2014:695028. Crossref

5. Sanchis-Alfonso V, Ginovart G, Alastruey-Lopez D, Montesinos-Berry E, Monllau JC, Alberich-Bayarri A, Perez MA. Evaluation of Patellar Contact Pressure Changes after Static versus Dynamic Medial Patellofemoral Ligament Reconstructions Using a Finite Element Model. J Clin Med 2019;8(12):2093. Crossref

6. Andrade R, Nunes J, Hinckel BB, Gruskay J, Vasta S, Bastos R, Oliveira JM, Reis RL, Gomoll AH, Espregueira-Mendes J. Cartilage Restoration of Patellofemoral Lesions: A Systematic Review. Cartilage 2019;1947603519893076. Crossref

7. Titchenal MR, Williams AA, Chehab EF, Asay JL, Dragoo JL, Gold GE, McAdams TR, Andriacchi TP, Chu CR. Cartilage Subsurface Changes to Magnetic Resonance Imaging UTE-T2* 2 Years After Anterior Cruciate Ligament Reconstruction Correlate with Walking Mechanics Associated With Knee Osteoarthritis. Am J Sports Med 2018;46(3):565-72. Crossref

8. Tanaka T, Matsushita T, Miyaji N, Ibaraki K, Nishida K, Oka S, Araki D, Kanzaki N, Hoshino Y, Matsumoto T, Kuroda R. Deterioration of patellofemoral cartilage status after medial open-wedge high tibial osteotomy. Knee Surg Sports Traumatol Arthrosc 2019;27(4):1347-54. Crossref

9. Niemeyer P, Schubert T, Grebe M, Hoburg A. MatrixAssociated Chondrocyte Implantation Is Associated with Fewer Reoperations Than Microfracture: Results of a Population-Representative, Matched-Pair Claims Data Analysis for Cartilage Defects of the Knee. Orthop J Sports Med 2019;7(10):2325967119877847. Crossref
10. Song SJ, Park $\mathrm{CH}$. Microfracture for cartilage repair in the knee: current concepts and limitations of systematic reviews. Ann Transl Med 2019;7(Suppl 3):S3-108. Crossref

11. Beckmann R, Lippross $S$, Hartz C, Tohidnezhad M, Ferreira MS, Neuss-Stein S, Seekamp A, Nebelung S, Kweider N, Rath B, Jahr H, Pufe T, Varoga DJ. Abrasion arthroplasty increases mesenchymal stem cell content of postoperative joint effusions. BMC Musculoskelet Disord 2015;16(1):250. Crossref

12. Kumagai K, Akamatsu $Y$, Kobayashi H, Kusayama $Y$, Saito T. Mosaic Osteochondral Autograft Transplantation Versus Bone Marrow Stimulation Technique as a Concomitant Procedure with Opening-Wedge High Tibial Osteotomy for Spontaneous Osteonecrosis of the Medial Femoral Condyle. Arthroscopy 2018;34(1):233-40. Crossref

13. Brucker PU, Braun S, Imhoff AB. Mega-OATS technique-autologous osteochondral transplantation as a salvage procedure for large osteochondral defects of the femoral condyle. Oper Orthop Traumatol 2008;20(3):188-98. Crossref

14. Cotter EJ, Frank RM, Waterman BR, Wang KC, Redondo $\mathrm{ML}$, Cole BJ. Meniscal Allograft Transplantation with Concomitant Osteochondral Allograft Transplantation. Arthrosc Tech 2017;6(5):e1573-80. Crossref

15. Agarwalla A, Christian DR, Liu JN, Garcia GH, Redondo ML, Gowd AK, Yanke AB, Cole BJ. Return to Work Following High Tibial Osteotomy With Concomitant Osteochondral Allograft Transplantation. Arthroscopy 2020;36(3):808-15. Crossref

16. Leon SA, Mei XY, Safir OA, Gross AE, Kuzyk PR. Long-term results of fresh osteochondral allografts and realignment osteotomy for cartilage repair in the knee. Bone Joint J 2019;101-B(1_Supple_A):46-52. Crossref

17. Mestriner AB, Ackermann J, Gomoll AH. Patellofemoral Cartilage Repair. Curr Rev Musculoskelet Med 2018;11(2):188-200. Crossref

18. Godin JA, Hussain ZB, Sanchez A, Sanchez G, Ferrari MB, Cinque ME, Kennedy NI, Provencher MT. Multicompartmental Osteochondral Allografts of Knee and Concomitant High Tibial Osteotomy. Arthrosc Tech 2017;6(5):e1959-65. Crossref

19. Mahmoud A, Young J, Bullock-Saxton J, Myers P. Meniscal Allograft Transplantation: The Effect of Cartilage Status on Survivorship and Clinical Outcome. Arthroscopy 2018;34(6):1871-76.e1. Crossref

20. Samuelson EM, Brown DE. Cost-effectiveness analysis of autologous chondrocyte implantation: a comparison of periosteal patch versus type I/III collagen membrane. Am J Sports Med 2012;40(6):1252-8. Crossref

21. Komarek J, Valis P, Repko M, Chaloupka R, Krbec M. Treatment of deep cartilage defects of the knee with autologous chondrocyte transplantation: long-term results. Acta Chir Orthop Traumatol Cech 2010;77(4):291-5.

22. Ritsila VA, Santavirta $S$, Alhopuro $S$, Poussa M, Jaroma $H$, Rubak JM, Eskola A, Hoikka V, Snellman O, Osterman K. Periosteal and perichondral grafting in reconstructive surgery. Clin Orthop Relat Res 1994;(302):259-65. Crossref

23. Kish G, Hangody L. A prospective, randomised comparison of autologous chondrocyte implantation versus mosaicplasty for osteochondral defects in the knee. J Bone Joint Surg Br 2004;86-B(4):619. Crossref

24. Krill M, Early N, Everhart JS, Flanigan DC. Autologous Chondrocyte Implantation ( $\mathrm{ACl})$ for Knee Cartilage Defects: A Review of Indications, Technique, and Outcomes. JBJS Rev 2018;6(2):e5. Crossref 
25. Khan WS, Longo UG. $\mathrm{ACl}$ and $\mathrm{MACl}$ procedures for cartilage repair utilise mesenchymal stem cells rather than chondrocytes. Med Hypotheses 2011;77(2):309. Crossref

26. Gooding CR, Bartlett W, Bentley G, Skinner JA, Carrington $\mathrm{R}$, Flanagan A. A prospective, randomised study comparing two techniques of autologous chondrocyte implantation for osteochondral defects in the knee: Periosteum covered versus type I/III collagen covered. Knee 2006;13(3):203-10. Crossref

27. Basad E, Wissing FR, Fehrenbach P, Rickert M, Steinmeyer $\mathrm{J}$, Ishaque B. Matrix-induced autologous chondrocyte implantation $(\mathrm{MACl})$ in the knee: clinical outcomes and challenges. Knee Surg Sports Traumatol Arthrosc 2015;23(12):3729-35. Crossref

28. Enea D, Cecconi S, Busilacchi A, Manzotti S, Gesuita R, Gigante A. Matrix-induced autologous chondrocyte implantation (MACI) in the knee. Knee Surg Sports Traumatol Arthrosc 2012;20(5):862-9. Crossref

29. Meyerkort D, Ebert JR, Ackland TR, Robertson WB, Fallon $\mathrm{M}$, Zheng $\mathrm{MH}$, Wood DJ. Matrix-induced autologous chondrocyte implantation (MACl) for chondral defects in the patellofemoral joint. Knee Surg Sports Traumatol Arthrosc 2014;22(10):2522-30. Crossref

30. Bartlett W, Skinner JA, Gooding CR, Carrington RW, Flanagan AM, Briggs TW, Bentley G. Autologous chondrocyte implantation versus matrix-induced autologous chondrocyte implantation for osteochondral defects of the knee: a prospective, randomised study. J Bone Joint Surg $\mathrm{Br} 2005 ; 87-$ $B(5): 640-5$. Crossref

31. Cugat R, Alentorn-Geli E, Navarro J, Cusco X, Steinbacher G, Seijas R, Alvarez-Diaz P, Barastegui D, Laiz P, Samitier G, Garcia-Balletbo M. A novel autologous-made matrix using hyaline cartilage chips and platelet-rich growth factors for the treatment of full-thickness cartilage or osteochondral defects: Preliminary results. J Orthop Surg (Hong Kong) 2020;28(1):2309499019887547. Crossref

32. Li X, Liang Y, Xu X, Xiong J, Ouyang K, Duan L, Wang D. Cellto-Cell Culture Inhibits Dedifferentiation of Chondrocytes and Induces Differentiation of Human Umbilical CordDerived Mesenchymal Stem Cells. Biomed Res Int 2019;2019:5871698. Crossref

33. To K, Zhang B, Romain K, Mak C, Khan W. SynoviumDerived Mesenchymal Stem Cell Transplantation in Cartilage Regeneration: A PRISMA Review of in vivo Studies. Front Bioeng Biotechnol 2019;7:314. Crossref
34. Rosadi I, Karina K, Rosliana I, Sobariah S, Afini I, Widyastuti $\mathrm{T}$, Barlian A. In vitro study of cartilage tissue engineering using human adipose-derived stem cells induced by plateletrich plasma and cultured on silk fibroin scaffold. Stem Cell Res Ther 2019;10(1):369. Crossref

35. Liu C, Li Y, Yang Z, Zhou Z, Lou Z, Zhang Q. Kartogenin enhances the therapeutic effect of bone marrow mesenchymal stem cells derived exosomes in cartilage repair. Nanomedicine (Lond) 2019;15(3):273-88. Crossref

36. Freyria AM, Mallein-Gerin F. Chondrocytes or adult stem cells for cartilage repair: the indisputable role of growth factors. Injury 2012;43(3):259-65. Crossref

37. Cugat R, Cusco X, Seijas R, Alvarez P, Steinbacher G, Ares O, Wang-Saegusa A, Garcia-Balletbo M. Biologic enhancement of cartilage repair: the role of platelet-rich plasma and other commercially available growth factors. Arthroscopy 2015;31(4):777-83. Crossref

38. Ekenstedt KJ, Sonntag WE, Loeser RF, Lindgren BR, Carlson CS. Effects of chronic growth hormone and insulin-like growth factor 1 deficiency on osteoarthritis severity in rat knee joints. Arthritis Rheum 2006;54(12):3850-8. Crossref

39. Zhang M, Zhou Q, Liang QQ, Li CG, Holz JD, Tang D, Sheu TJ, Li TF, Shi Q, Wang YJ. IGF-1 regulation of type II collagen and MMP-13 expression in rat endplate chondrocytes via distinct signaling pathways. Osteoarthritis Cartilage 2009;17(1):100-6. Crossref

40. Moore EE, Bendele AM, Thompson DL, Littau A, Waggie KS, Reardon B, Ellsworth JL. Fibroblast growth factor-18 stimulates chondrogenesis and cartilage repair in a rat model of injury-induced osteoarthritis. Osteoarthritis Cartilage 2005;13(7):623-31. Crossref

41. Barr L, Getgood A, Guehring H, Rushton N, Henson FM. The effect of recombinant human fibroblast growth factor-18 on articular cartilage following single impact load. J Orthop Res 2014;32(7):923-7. Crossref

42. Okuda K, Kawase T, Momose M, Murata M, Saito Y, Suzuki H, Wolff LF, Yoshie H. Platelet-rich plasma contains high levels of platelet-derived growth factor and transforming growth factorbeta and modulates the proliferation of periodontally related cells in vitro. J Periodontol 2003;74(6):849-57. Crossref

43. Hall MP, Band PA, Meislin RJ, Jazrawi LM, Cardone DA. Platelet-rich plasma: current concepts and application in sports medicine. J Am Acad Orthop Surg 2009;17(10):6028. Crossref 